Неретина С. С. «Бобок» как зеркало удивления // Философия. Журнал Высшей школы экономики. -2021 . - Т. 5, № 4. - С. 157-174.

\title{
Светлана Неретина*
}

\section{«БОБОК》 КАК ЗЕРКАЛО УАИВЛЕНИЯ**}

Получено: 12.06.2021. Рецензировано: 19.09.2021. Принято: 01.10.2021.

Аннотация: В статье рассматривается феномен, с одной стороны, зеркала, в котором любая вещь, субъект-человек прежде всего- фиксированы в отражении, дающем возможность наблюдать за собою ради самопонимания, с другой стороны-границы, главным образом границы между жизнью и смертью, которую с помощью определенных ментальных и физиологических процессов, влияющих на психоэмоциональное состояние (в данном случае-сон) можно пересечь для той же цели. Оба феномена, кажущиеся схожими, на деле разные: в одном случае поставлен акцент на созерцании, в другомна умозрении и слухе, настроенном на голос другого мира. Здесь не случайно избранное Аостоевским место события: кладбище как граница между жизнью и смертью и кладбищенский памятник как символ памяти, где герой «соответственно задумался». Поскольку герой рассказа находится в неадекватном состоянии после похорон, то тема мениппеи, серьезно-смехового жанра, возникает словно бы сама собой, тем более что М. М. Бахтин считал рассказ «Бобок» «одной из величайших мениппей в мировой литературе». Автор статьи думает, что подход Бахтина к рассказу с позиций мениппеи оправдан, ибо он определяет этот жанр не с точки зрения производимого им эффекта на читателя, а с позиции философии поступка, что Бахтин полагал истинным определением этого жанра. Автор обращает внимание на «логику поворота», или тропо-логику, на основании которой выстроен рассказ с его оксюморонами, сравнениями, иронией. Рассказ, по мнению автора, характеризует не амбивалентность, а схождение начал и концов. Философская мысль одного из персонажей рассказа соотносит идеи живъх и мертвъх, т. е. находящихся в разных пространственно-временных реальностях, так, что они кажутся встроенными друг в друга. Это сходство, не лишающее рассказ карнавализации, всегда связанной с двойственностью, внутренне сосредоточено на идее единомыслия, имеющего один источник, предугадывая еще не родившийся вопрос о способе модификации бытия в возможности в бытие в действительности.

Ключевые слова: нарциссизм, Бобок, мениппея, диалог, граница, жизнь, смерть, сон. DOI: $10.17323 / 2587-8719-2021-4-157-174$.

\section{НАРЦИССИЗМ КАК ВВЕДЕНИЕ В ПРОБЛЕМУ САМОПОНИМАНИЯ}

В наше время весьма распространено понятие «нарциссизм», перекочевавшее из психологии в философию и сохранившее в обеих значение восприятия себя как уникального индивида, правда, как иногда говорят, «немного более уникального, чем другие». А. В. Рубцов много

*Неретина Светлана Сергеевна, д. филос. н., профессор, главный научный сотрудник Института философии Российской академии наук (Москва), abaelardus@mail.ru, ORCID: 0000-0002-2063-062X.

** (C) Неретина, С. С. (C) Философия. Журнал Высшей школы экономики. 
и интересно писал об этом феномене, который в принципе может относиться к любому человеку, но прежде всего к человеку власти, поэтому Рубцов и сфокусировал свое внимание на политическом нарциссизме. Рефлексия по поводу этого феномена весьма серьезна. Речь о том, как относиться к зеркалу, в которое человек необходимо смотрится в силу наблюдения самим собою за самим собою ради самопонимания. Как писал Рубцов,

нарциссизм «субъективно идеалистичен» уже тем, что субъект фиксирован именно на отражении - имидж, эфирная картинка, символический статус, просто впечатление и «впечатление второго порядка» (впечатление от впечатления). Нарциссу в конечном счете важно не то, как его реально оценивают, а как выглядит это чужое восприятие, как он сам это чужое восприятие воспринимает (Рубцов, 2016).

Собственно, вот это последнее - восприятие чужого восприятия и интригует, если читать «Дневник писателя» Ф. М. Достоевского, который он начал вести с 1873 г. в ж. «Гражданин», и, в частности, опубликованный внутри «Дневника» небольшой рассказ со смешным и непонятным названием «Бобок».

С позиций нарциссизма, т. е., казалось бы, с совершенно другого ракурса, проблема, структура и смысл этого произведения Достоевского выглядят иначе. Часто, анализируя «Бобок», интерпретаторы словно забывают, что перед ними тройной взгляд со стороны рассказчика, автора и читателя. Это взгляды во взгляде и на взгляд. Сам Достоевский объяснил свое решение вести «Дневник» так: он хотел именно посмотреть на себя как в зеркало: «Буду и я говорить сам с собой. [...] Об чем говорить? Обо всем, что поразит меня или заставит задуматься» (Д15. Т. 12: 49). Но, судя по всему, критика, упрекавшая писателя в том, что его герои - слепок с него самого, привела его к иронической самообороне. В кратчайшем предисловии к «Бобку» он написал: «На этот раз помещаю „Записки одного лица“. Это не я; это совсем другое лицо». Это ли не введение в проблему остранения и отстранения: что-де о себе писать, это не я, это вон то или тот, я на него могу пальцем указать. И действительно- оно, это третье лицо, Иван Иваныч, как «фриц» вообще, как «иваны» вообще, ведет себя как антинарцисс. Пьяница-писатель Иван Иваныч, герой «Бобка», заявляет в ответ на укоризну, что он вечно пьян:

Я не обижаюсь, я человек робкий; но, однако же, вот меня и сумасшедшим сделали. Списал с меня живописец портрет из случайности: «Все-таки ты, 
говорит, литератор». Я дался, он и выставил. Читаю: «Супайте смотреть на это болезненное, близкое к помешательству лицо».

Он видит себя другим. Другим его видит и Достоевский, он, так сказать, другой в квадрате.

Антинарциссизм - его кредо. Он не любуется собой. Он понимает мерзость свою. И эту свою мерзость он понимает по Пушкину. Тот в письме П. А. Вяземскому в 1925 г. писал (Пушкин, 1962: 216):

Толпа жадно читает исповеди, записки еtс., потому что в подлости своей радуется унижению высокого, слабостям могущего. При открытии всякой мерзости она в восхищении. Он мал, как мы, он мерзок, как мы! Врете, подлецы: он и мал и мерзок-не так, как вы-иначе.

И как Пушкин же соглашается, что

писать свои Mémoires заманчиво и приятно. Никого так не любишь, никого так не знаешь, как самого себя. Предмет неистощимый. Но трудно. Не лгатьможно; быть искренним - невозможность физическая. Перо иногда остановится, как с разбега перед пропастью-на том, что посторонний прочел бы равнодушно. Презирать [...] суд людей не трудно; презирать суд собственный невозможно (там же).

В чем ирония? Слог бы надо бы соблюсти. А потому говорит, что литератор он никакой.

Это первое расщепление автора и рассказчика. Вряд ли Достоевский стал эдаким образом характеризовать себя. А тот рекламы купцам пишет, фельетоны сочиняет, по заказу написал «Искусство нравиться дамам».

Вот этаких книжек я штук шесть в моей жизни пустил. Вольтеровы бонмо хочу собрать, да боюсь, не пресно ли нашим покажется. Какой теперь Вольтер; нынче дубина, а не Вольтер! Последние зубы друг другу повыбили! Ну вот и вся моя литературная деятельность (Д15. Т. 12: 50).

\section{ФИЛОСОФСКАЯ МЕНИППЕЯ}

Это, разумеется, очевидно заявленный антинарцисс, хотя и с привкусом нарциссизма. Нарцисс статичен, он недвижно смотрит на себя, а если бы сдвинулся, то заметил бы изменение. А здесь ирония зашкаливает:

Думаю, что живописец списал меня не литературы ради, а ради двух моих симметрических бородавок на лбу: феномен, дескать. Идеи-то нет, так они 
теперь на феноменах выезжают. Ну и как же у него на портрете удались мои бородавки, - живые! Это они реализмом зовут (Д15. Т. 12: 50).

Федора Михайловича действительно записывали, а в Википедии и сейчас записали в реалисты. Основания такой записи не выяснены: «он-де создавал реалистические произведения», хотя при этом всего лишь «встраивал свои произведения в окружающую его действительность, а не создавал для них новую». Основанием для записи его в реалисты считают его внимание к «деталям, мелочам, случайным происшествиям, скандалам и преступлениям [...] цифровым уточнениям». «Цифровые уточнения» мгновенно вызывают в памяти Гоголя с его «мартобрем 86 числа» и мешают Достоевского привязывать к литературному реализму. Хотя с Гоголем связи у Достоевского, и в «Бобке» в том числе, немаловажные. Ссылка на Википедию здесь не случайна: статья обширная, студенты ее точно будут читать, определение Достоевского в реалисты запомнят как клише.

Рассказ был плохо встречен читающей публикой, даже как-то презрительно (см. Хамитов, 2016; Милнер-Галланд и Соболева, Погорелая, 2012; Д15. Т. 12: 315-324). Но вот истинный знаток поэтики Достоевского М.М. Бахтин отнес «Бобок» «по своей глубине и смелости к одной из величайших мениппей во всей мировой литературе» (Бахтин, 2002: 81). Более того, он назвал его «почти микрокосмом всего его творчества» и считал, что

очень многие, и притом важнейшие, идеи, темы и образы его творчестваи предшествующего, и последующего-появляются здесь в предельно острой и обнаженной форме (там же: 85).

Что такое мениппея? Это вид серьезно-смехового жанра. Термин использовался М. М. Бахтиным в «Проблемах поэтики Достоевского». Варрон в I в. до н.э. написал книгу с названием «Менипповы сатиры», которое и послужило для определения Бахтиным жанра. Но он видел разницу между мениппеей и «Менипповыми сатирами». Мениппея, на его взгляд, в отличие от менипповой сатиры, охватывает литературные явления разных эпох: это новеллы и философские повести Средневековья и Возрождения. По мнению М. Л. Гаспарова, Бахтин, однако, возвеличивает этот жанр искусственно и действует не как филолог, а как философ, для которого важна этика поступка и его становления, а не система литературного произведения (см. Гаспаров, 2004).

Увидеть в хотя и серьезной, но смешной мениппее философию поступка-это, собственно, и есть определение жанра, а вовсе не отрицание 
«системы литературного произведения», тем более что Бахтин- действительно философ par excellence. Увеличение удельного веса смехового элемента, отсутствие требований правдоподобия сюжета с целью создания исключительных ситуаций для провоцирования и испытания философской идеи, сочетание глубокой символики с крайним и грубым трущобным натурализмом - это принципы, которые Бахтин устанавливает (если устанавливает) для мениппеи, не тождественной «Менипповым сатирам». А поскольку Достоевский с самого начала, как бы в предисловии к рассказу, ставит истинно философскую проблему ума, мышления как принадлежащего любому человеку, обладающего амбивалентностью, при которой выявляется относительность разума и безумия, - то рассматривать Бахтина как мыслителя, который «возвел художественное мышление Достоевского на высоты предельного философского пафоса» (Библер, 1991: 98-99), - наша обязанность.

Именно эта жесткость постановки вопроса позволяет разделить мир на мир громкого слова и мир тишинъ - кладбищенский, изначально тревожный. Различие между умными и сумасшедшими рассказчик, которого иногда считают проводником идей самого Достоевского, ставит в зависимость от политики - то ли государственной, то ли общественной (что, например, представляют собой упоминаемые «испанцы»?, «французы»?), потому что в сумасшедшие записывают талантливых людей, умеющих сводить с ума (делать сумасшедшими? учить удивляться?), но никого умными не делающих. Нелепость-отождествление идей Достоевского с идеями автора «Записок», того, о ком говорится «один человек рассказал мне», какой-то Иван Иваныч. Здесь с самого начала вводится «остраняющий» метод-ирония, которая даже очень серьезным рассуждениям придает насмешливый, «не тот» оттенок. Герой сам полунасмехается, полувопрошает - не-до-умевает над своими размышлениями по поводу того, что такое ум и что такое безумие,как и бывает с философствующим человеком, споткнувшимся об ум как краеугольный камень своего существования.

Само это русское слово «ум» сходно с ударом топора-《ух!». Достоевский явно это замечает, потому что вкладывает в уста того самого «одного лица» рассуждения другого лица о его слоге (Д15. Т. 12: 51):

У тебя, говорит, слог меняется, рубленый. Рубишь, рубишь - и вводное предложение, потом к вводному еще вводное, потом в скобках еще что-нибудь вставишь, а потом опять зарубишь, зарубишь... 
Речь - это то, что является знаковым материалом внутренней жизни, если следовать Бахтину-Волошинову (Волошинов [Бахтин], 1993: 19), в речи слово еще клекочет, еще только рождается. Этим объясняется, что у Ивана Иваныча «и характер меняется, и голова болит». Он начинает

видеть и слышать какие-то странные вещи. Не то чтобы голоса, а так как будто кто подле: «Бобок, бобок, бобок!» (Д15. Т. 12: 19)

Бобок - росток, что-то в нем прорастает и выходит вовне по известному присловью «у пьяного на языке». Но если «бобок» повторять подряд много раз без перерыва, то можно опознать «обок» ${ }^{1}$, вроде «живем с тобой бок о бок», а поскольку затем пойдет речь о «другом» мире, то эта омонимия много значит. Впрочем, в рассказе много омонимий (например, упомянутое «рубить» или «тронуться»-начать ходить, сходить с ума, тлеть).

Амбивалентность - нынче редко употребляющееся слово. Когда в 1960-е стали выходить после затишья книги Бахтина, оно было в ходу у интеллектуалов. K этому же рассказу оно особенно применимо. Так, например, пытаясь выяснить, «какой такой бобок», автор «Записок» идет развлекаться, но попадает на похороны. Про амбивалентность забывать нельзя, как нельзя этот рассказ считать порнографическим, исполненным horror, черным юмором, который был направлен на циничное общество того времени. Я бы даже и черной сатирой не стала считать «Бобок» (Алексеев, 2013), не говоря уже о том, что рассказ не дает оснований и для апокалиптических тонов, тем более обозначенных словами «тошнотворные образы», в которых выражена и «мучительная тревога за безбожное человечество», и для подхода к «Бобку» как к «самому страшному из метафизических воззрений Достоевского» (Мочульский, 1947: 393), хотя можно найти и такие образы, и метафизику; спокойнее назвать - «предостережение» и «увещание» (Джексон, Бузина и Гулева, 1998: 231). Кажется, однако, что, несмотря на весь описываемый в «Бобке» гвалт мертвецов (хаос, как сказал Гаспаров), дело в бахтинском остранении. Стоит об этом подумать, как все «видишь» спокойнее, строже, сосредоточеннее.

${ }^{1}$ Милнер-Галланд, однако, считает, что в этом слове можно (в ударном слоге) расслышать слово «Бог» (Милнер-Галланд и Соболева, Погорелая, 2012). Впрочем, в этой же работе упоминается имя модного писателя 1870-х гг. Петра Боборыкина, от фамилии которого М. Е. Салтыков-Щедрин предположительно образовал глагол «боборыкать». 
Описание кладбища и похорон, построенное на оксюморонных сочетаниях, проникнуто, как говорит Бахтин, «подчеркнутым фамильярным и профанирующим отношением» и к месту, и к самому событию, «полно снижений и приземлений, карнавальной символики и одновременно грубого натурализма» (Бахтин, 2002: 82).

Мертвецов пятнадцать наехало. Покровы разных цен; даже было два катафалка: одному генералу и одной какой-то барыне. Много скорбных лиц, много и притворной скорби, а много и откровенной веселости. Причту нельзя пожаловаться: доходы. Но дух, дух. Не желал бы быть здешним духовным лицом (Д15. Т. 12: 51).

Не лучше и описания мертвецов, отпевания, размышления о ценах на захоронения, изображение округи с богадельней и ресторанчиком, где «много заметил веселости и одушевления искреннего. Закусил и выпил» (там же: $5^{2}$ ).

Вот эти «резкие оттенки фамильяризации и профанации» Бахтин и считает «сгущенным образцом стиля карнавализованной мениппеи» (Бахтин, 2002: 82), очевидно связанным с неким поступком (закусил и выпил), приведшим к неожиданным последствиям. Но кажется все же, что, несмотря на заплетающийся язык и обрывочные рассказы, в уме Ивана Иваныча упрямо держится главный, почти - хотя до этого еще далеко - пастернаковский вопрос, заготовленный для Сталина: о жизни и смерти, где за внешней размагниченностью прячется лишенный мужества страх. Кладбище как граница жизни и смерти, где живые и мертвые рядом. Неслучайно шатания Ивана Иваныча окачиваются не просто тем, что он «сел на памятник» - символ памяти - и «соответственно задумался». Мысли, судя по всему, бегали: начал с московской выставки, а закончил удивлением, с которого, как с давних пор известно, начинается познание.

Тема удивления вовсе не «зыбкое размышление», как полагает Бахтин, и даже не потому, что Иван Иваныч зачем-то разворачивает довольно пошлое мнение, что не удивляться принято за хороший тон, и не потому, что это моветонное мнение сочетается с темой уважения, принятого у пьяниц,--эта вроде пошлость (возникшая из удивления и страха) позволяет пересечь границу между жизнью и смертью, оно прямо и непосредственно вводит в загробный мир. И он оказывается зеркальным. 


\section{СОН КАК ПРОСТРАНСТВО СХОЖДЕНИЯ РАЗНЫХ РЕАЛЬНОСТЕЙ}

Сама по себе эта тема - попадание в загробный мир-древняя, не говоря о прочих сюжетах о путешествиях, упоминаемых Бахтиным в связи с темой мениппеи (например, Лукиановых «Мениппе, или Путешествии в загробное царство» и «Разговорах в царстве мертвых»); достаточно вспомнить грандиозное путешествие Данте, услышавшего голос самого Ада («Я увожу к отвергнутым селеньям, // Я увожу сквозь вековечный стон, // Я увожу к погибшим поколеньям. // Был правдою мой зодчий вдохновлен: // Я высшей силой, полнотой всезнанья // И первою любовью сотворен»). «Сниженное» описание пересечения границы в «Бобке» лишь подчеркивает оглядку на классическую высоту первоисточника: то скромное «одно лицо», кому принадлежат «Записки», находится не в катарсическом состоянии духа, а в состояния духа запойного, но который тоже уносит в ту высь, где все тождественно, поскольку он отождествляет состояние сидя с состоянием лежа («сидел [...]; то есть даже прилег»), и где сон оказывается тормозом для разделения, соединяющим и роднящим высокое и низкое - Дантово «настолько сон меня опутал ложью» соседствует с «забытьем» и «голосами» Ивана Иваныча.

Рассказ «Бобок» сравнивают с «Божественной комедией» давно. Например, IX главу первой части «Записок из Мертвого дома» (Акелькина, 2012: 394). В. К. Кантор, считая, что в «Дневнике писателя» «вечные проблемы Достоевский решал на актуальных сюжетах, ставя их в контекст ,Последних вопросов“» (Кантор, 2004: 4), тоже сопоставляет творчество Достоевского с Данте, упоминая при этом и западных мыслителей, рассуждавших на эту тему (Шпенглера). Он, однако, подчеркивает, что сравнение всегда хромает, не давая «понимания нового явления в его целостности», и кивает при этом на О. Шпенглера. Надо принять опыт «Мертвого дома», который вносит существенные коррективы в размышления о потустороннем мире.

Если,- - пишет он, цитируя современного исследователя, - в основе поэтики «Комедии» Данте заложена идея высшей справедливости миропорядка, то в «Записках...» Достоевского в изображении эмпирической реальности Мертвого дома идея справедливости превращается по крайней мере в вопрос (там же; Тоичкина, 2012: 164).

Можно при этом сослаться и на «Бобок», не говоря уже о сравнении его со средневековыми видениями, рассказами и их толкованиями. 
Некий человек по имени Ператин со следами сказал сыну и соседям: «Увы, увы мне! В саду у меня растет дерево, приносящее несчастье. На нем повесилась моя первая жена, затем вторая, наконец, третья, и потому я в неутешном горе». Один из слушавших его жалобы по имени Аррий говорит: «Я удивляюсь, что ты горюешь в подобных обстоятельствах. Дай мне, будь добр, три побега этого дерева, я раздам их соседям. Пусть у каждого будет сук, на котором могла бы повеситься его жена». Так и было сделано.

Но вот мораль: «Любезнейшие! Этим деревом был Крест, на котором висел Христос»². Чем не «Бобок»?

Можно, правда, при сравнении с Данте говорить о противопоставлении, ибо при схожести адовых картин осмысление все же другое: у Данте-теология сна, у Достоевского-эмпирия сна, как и вообще другой герой и другая эмпирия. Здесь надо бы скорее размышлять не о знаковой символике, а о перформативности знака, обладающего способностью к мгновенному переключению сказанного в действие. И. И. Евлампиев, на которого также ссылается Кантор, когда писал, что

«Бобок» можно рассматривать как предположение о возможной форме существования человека в той перспективе, которую открывает нам «высшая идея» о бессмертии, и это предположение поражает своей безысходностью и выглядит даже более ужасным, чем представление о вечности в виде бани с пауками, пугающее Свидригайлова (Евлампиев, 2012: 449),

говорил все же о другом - о другой стилистике. «Бобок», конечно, можно рассматривать с точки зрения вечности, с позиций православной церкви о бессмертии души, с позиций обличения общественного цинизма, понимания предвечной жизни, в которой еще есть стыд, но все это оставляет впечатление, что это-не о рассказе «Бобок». В нем все двоится («выпил-закусил») и все переворачивается («ходил развлекаться, а попал на похороны» 3 ).

В «Бобке» все смешно. Кажется, что зацикленность Бахтина на мениппее возникла именно оттого, что не только в наше, но и в его время этого смеха не слышали, потому что именно смех со свойственной ему гораздо более сильной философской интенцией исключен из всех этих, безусловно, умных суждений. Когда пугают «мучительной тревогой

${ }^{2}$ Цитаты из Oesterley, 1872 даются по: Неретина, 1993: 151-152, 159-160.

3 Явная отсылка к грибоедовскому «шел в комнату - попал в другую». Отсылки Достоевского к литературе столь велики в этом маленьком рассказе, что можно «Бобок» сделать фокусом, сквозь который просматривается все ее цветение. 
за безбожное человечество», то речь может идти о мировоззрении Достоевского, но не о рассказе «Бобок», где у «загробных» людей нет никакой тревоги ни за себя, ни за человечество. Она появляется у Ивана Иваныча, но не слишком решительно.

Разврат в таком месте, разврат последних упований, разврат дряблых и гниющих трупов и - даже не щадя последних мгновений сознания! Им даны, подарены эти мгновения и... А главное, главное, в таком месте! Нет, этого я не могу допустить... (Д15. Т. 12: 57)

Точнее, совсем нерешительно: «И это современный мертвец!» (там же) Вот, казалось бы, и «мучительная тревога», но...

Побываю в других разрядах, послушаю везде. То-то и есть что надо послушать везде, а не с одного лишь краю, чтобы составить понятие. Авось наткнусь и на утешительное (там же: 64. Курсив мой.-С.Н.).

$\mathrm{K}$ «тем» он тоже собрался вернуться, но опять же не для обличения: «Обещали свои биографии и разные анекдотцы». И хоть «тьфу! Но пойду, непременно пойду; дело совести!» (там же), но под совестью явно понимается не совесть, а возвращение.

Правда российской жизни и в том самом разворачивающемся нигилизме (пишу не с отрицательной позиции, а лишь для обозначения направления, весьма занимавшего Федора Михайловича и ставящего под сомнение общепринятые понятия, по крайней мере обмысливающего их).

В. В. Бибихин начинает «Толкование сновидений» с размышления о философии: она открывается тогда, когда она-«захваченность», когда она - судьба, когда она то, чего уже не потерять, когда она

затмевает своим блеском все земное и ослепляет нас тоже [...] При встрече с идеей человек не становится вооруженным, наоборот, разоружается (Бибихин, 2001: 15).

У Бибихина такой человек слепнет. Иван Иваныч в рассказе «Бобок» тоже закрывает глаза, но не слепнет, а открывает слух. Он начинает слышать другой мир. Он, находящийся в состоянии полуснаполубодрствования, стал «внимательно вслушиваться».

О чем философия? Сошлюсь снова на Бибихина, умевшего найти точные слова для того, что у другого не выговаривается.

Философия не интеллектуальная деятельность [...] Философ не для того чтобы так или по-другому войти в нашу картину истории философии. Он для того чтобы показать нам, где наши картины, наши сны и где то упущенное, о чем сны (там же: 19). 
Это вполне созвучно мыслям Достоевского, который пишет о том, что его поражает. Пишет, используя простое, в чем-то загубленное, но сохранившее странное понимание языков мира, даже если язык другой стороны мира похож на наш, а может быть именно поэтому мы его и знаем, если знать и то, что похожесть ведет к сравнению, а значит - не тождеству. Бахтин дальнейшее развитие сюжета называет анакризой, провокацией «исключительной силы», заставляющей собеседника до конца высказать свое мнение.

А собеседниками оказываются мертвецы-пограничники, т. е. недавно усопшие, находящиеся, как давным-давно говорил Августин, в состоянии после первой смерти до Страшного суда, когда либо полностью умрут, либо восстанут к новой жизни. Что они делают? Сражаются в преферанс. Немереное удивление!

Голоса «веские и солидные» (генеральский, как подсказывает надпись на памятнике), «льстивые» (надворный советник, как подсказывает слух), простонародно-расслабленные, дамские «брезгливые и высокомерные» (Д15. Т. 12: 52, 53). И «там» сохраняется иерархия: граф, оказавшийся бароном, генерал, тайный советник, советник надворный, инженер, негоциант, лавочник, девица с пониженной социальной ответственностью. Но дело не в иерархии, а в том, что здесь хранится весь разночинный и разно ощущающий свои сощиальные роли народ и-в этом, конечно, особость Достоевского-мир: шулеры, воры, развратники с мечтами о блондиночке и с разговорами о пище, картах, икоте, обсчетах в лавке, о неослабном желании пожить, о проекте новой (не комиссии, а) подкомиссии в министерстве, о болезнях и о скуке, поскольку речи все те же. Но удивление безграничное, поскольку граница между двумя мирами оказалась столь прозрачной, что вызвала поистине уникальное внутреннее полуосуждающее восклицание Ивана Иваныча: «И это современный мертвец!»

Это странное (и очень смешное) восклицание, смешивающие ряды времени, спровоцировало появление еще одной фигуры - философа. Правда, «доморощенного», но остепененного- -естественника и магистра. [...] Он несколько философских книжек пустил» (там же: 61).

Бахтин считает речь умершего философа Платона Николаевича аллюзией на «сократический диалог» и, конечно, «анакризой, провоцирующей сознание мертвецов раскрыться с полной, ничем не ограниченной свободой» (Бахтин, 2002: 82). Именно в уста Платона Николаевича вложено объяснение факту посмертной жизни современных покойников (Д15. Т. 12: 61): 
Он (Платон Николаевич. - М. Б.) объясняет это самым простым фактом, именно тем, что наверху, когда еще мы жили, то считали ошибочно тамошнюю смерть за смерть. Тело здесь еще раз как будто оживает, остатки жизни сосредоточиваются, но только в сознании. Это-не умею вам выразитьпродолжается жизнь как бы по инерции. Все сосредоточено, по мнению его, где-то в сознании и продолжается еще месяца два или три... иногда даже полгода... Есть, например, здесь един такой, который почти совсем разложился, но раз недель в шесть он все еще вдруг пробормочет одно словцо; конечно, бессмысленное, про какой-то бобок: «Бобок, бобок».

Бахтин считает, что этим «развертывается типическая карнавализованная преисподняя мениппеи» (Бахтин, 2002: 78). Но не совершается ли здесь другое - сращение начал и концов? Философская мысль Платона Николаевича совместила (или вместила, соотнесла) последние мысли некоего усопшего с последними захватывающими мыслями живого, хотя и полуспящего Ивана Иваныча, тоже слышавшего «Бобок, бобок» оборачивающимся «обок, обок», но и «концом», ведь граница - это не только междоусобная территория, но и конец? Мысли одного будто вложены в мысли другого, живущего в другом времени и уж точно находящегося в другом месте. Это сходство, не лишающее рассказ внешней карнавализации, всегда имеющей дело с двойственностью, внутренне сосредоточено на идее единомыслия, имеющего один источник, предугадывая еще не родившийся вопрос (Хайдеггер, Черняков, 2001: 115-116):

Каким образом реальность, бытие в возможности, модифицируется в действительность в акте осуществления, т. е. когда действительность присоединяется?

Это в чем-то сродни средневековой мистике, смысл которой именно в попытке понять «некоторое сущее, полагаемое онтологически в качестве некоторой сущности - Бога - понять в самом его естестве» (там же: 117). И хотя это сказано о высшем сущем-Боге, это единство может быть проявлено в каждом «некотором сущем». То есть Достоевский проделывает обратный ход относительно Бахтина. Он усматривает действительное в том, что когда-то было возможным. Это уже ход не автора «Записок одного лица», а автора рассказа «Бобок», что, разумеется, превращает речь в диалогическую, внутренне, глубоко диалогическую, но нацеленную не на дискурсию карнавала, а на конкурсию единства. Собственно желание почти всех мертвецов «не стыдиться», если его перевести в регистр последнего знания, где все вещи тождественны, действительно означает своего рода исповедальную свободу, 
заключающуюся в том числе и в призыве одного из главных «негодяев псевдовысшего света» барона Клиневича «не лгать» (Д15. Т. 12: 58, 62). Так как, по его словам, «на земле жить и не лгать невозможно, ибо жизнь и ложь синонимы», или-«гнилые веревки» (там же: 62).

Признание тождества земной жизни и лжи, соответственно тождества вечности и истины, послужило возвратом Ивана Иваныча с границы в место его пока еще временного пребывания.

И тут я вдруг чихнул. Произошло внезапно и ненамеренно, но эффект вышел поразительный: все смолкло, точно на кладбище, исчезло, как сон. Настала истинно могильная тишина (там же: 63-64).

Главное здесь - не чих. Главное - «внезапно и ненамеренно», неумышленно и бессознательно явленное состояние одномирия, сменившее мировую полифонию.

В несохранившейся работе «Философия поступка» Бахтин, собственно, и говорит об этом встраивании одного в другое, выстраивая событие, видя «в поступке выход из только возможности в единственность раз и навсегда» (Бахтин, 1986: 103), тем более что «мир такая вещь, что он существует во сне не меньше чем не во сне» (Бибихин, 2001: 115).

\section{ЗАКЛЮЧЕНИЕ КАК НЕДОУМЕНИЕ}

Итак, что случилось в рассказе «Бобок», который помещен в «Дневник писателя» за 1973 год? Помещен писателем, желавшим «говорить сам с собой [...]. [...] Обо всем, что поразит [...] или заставит задуматься». Ключевой фигурой в нем является рассказчик. Он - то зеркало, в котором все происходящее видится в обратной перспективе. Он-точка схождения «того» и «этого» мира. «Логика поворота», о которой мы говорили, это не просто некие художественные приемы, делающие рассказ смешным и вместе с тем горьким. Это речь преображения. И тем более не закругление себя в истории, если история «живого и мертвого» оказывается ложью, где нет никакого начинания, где «иной» мир делается не странным «этому» миру, а все превращающим в анекдот. Рассказчик волею автора, наверное, а может быть, ненароком по свойству воображения доверяет нам анекдот, поражающий всерьез. Страхи и ужасы, связанные с миром могил, известны, а вот анекдоту действительно свойственно, как пишут словари, «неожиданное смысловое разрешение в конце», которое обязательно вызовет смех, но со слезами на глазах. Он характеризует не столько амбивалентность, сколько неожиданное схождение вместе всего земного, поскольку и живые, и мертвые- на 
земле, и мертвые «хватают» живых, как мысль захватывает человека. Философия одного из персонажей рассказа соотносит мысли живых и мертвых, т. е. находящихся в разных пространственно-временных, но земных реальностях, так, что они кажутся встроенными друг в друга.

Антинарциссизм Достоевского показал горе нарциссизма. Это горе и в лишаемости дифференции, и в схождении прямой и обратной перспектив при том, что обратная перспектива зазеркалья именно своим сходством с прямой (обыденной) реальностью поразила воображение рассказчика, которого недопустимо путать с автором. Он не рассказывал свой вымысел (значение слова «анекдот»), он его услышал. Рассказчик оказался репортером: он ведет речь не о чем-то ему уже известном, а о совершающемся вот сейчас небывалом, происходящем во сне, от которого он едва очнулся, ничего не сумев начать. Сон (отсутствующая реальность, место, которого нет) оказался живым репортажем оттуда, куда можно войти только по смерти. Он оказался свидетелем неведомого, позволив не увидеть, но обнаружить событие, уже и еще не ставшее, таинственное, не усмиренное, а потому можно подумать, что и все действительное нам снится. Не случайно рассказ не приняли читатели, он как бы еще не издан - еще одно значение слова «анекдот». Впрочем, иные подсмеиваются и над Б. Латуром, убежденным, что новое общество должно учитывать и людей и не-людей, вирусы и бактерии той Геи, которая не является природой, объектом галилеевской механики, местом, где зародилась жизнь, а является местом, где происходит пересборка привычной среды (Латур, Полонская, 2014). Достоевский его опередил.

\section{СОКРАЩЕНИЯ}

Д15 Достоевский Ф. М. Полное собрание сочинений : в 15 т. / под ред. В. Н. Захарова. - М., Л. : Наука, 1988-1996.

Т. 12 : Дневник писателя, 1873. Статьи и очерки, 1873-1878/ под ред.

А. В. Архиповой, Г. Я. Галагана. - 1994.

\section{ЛитературА}

Акелъкина E. A. Данте и Достоевский (рецепция дантовского опыта организации повествования в «Божественной комедии» при создании «Записок из Мертвого дома») // Вестник Омского университета. - 2012. - № 2. - С. 394-399. Алексеев B. Тление тела как метафора греха : рассказ Достоевского «Бобок» Russian Lutheran. - 2013. - URL: http://www.russianlutheran.org/strannik /death_dostoevskiy.html (дата обр. 30 мая 2021). 
Бахтин M.M. К философии поступка // Философия и социология науки и техники : Ежегодник 1984-1985 / под ред. И.Т. Фролова. - М. : Наука, 1986. - С. 80-160.

Бахтин М. М. Проблемы поэтики Достоевского. - M., Augsburg : Im Werden Verlag, 2002.

Бибихин В. В. Слово и событие. - М. : УРСС, 2001.

Библер В. С. Михаил Михайлович Бахтин, или Поэтика культуры. - М. : Прогресс, Гнозис, 1991.

Волошинов В.Н. [Бахтин М. М.] Марксизм и философия языка : основные проблемы семиологического метода в науке о языке. - М. : Лабиринт, 1993.

Гаспаров М. Л. История литературы как творчество и исследование : случай Бахтина // Вестник гуманитарной науки. - 2004. - Т. 78, № 6. - С. 8-10.

Джексон Р. Л. Искусство Достоевского. Бреды и ноктюрны / пер. с англ. Т. Бузиной, Е. Гуляевой. - М. : Радикс, 1998.

Евлампиев И. И. Философия человека в творчестве Ф. Достоевского (от ранних произведений к «Братьям Карамазовым»). - М. : РХГА, 2012.

Кантор В.К. Проблема посмертного существования (от Платона до Достоевского). «Бобок», рассказ Достоевского // Germanoslavica. Zeitschrift für germane-slavische Studien. Literatur und Wissen. - 2004. - № 29. - C. 63-76.

Латур Б. Пересборка социального : введение в акторно-сетевую теорию / пер. с англ. И. Полонской. - М. : Изд. дом Высшей школы экономики, 2014.

Милнер-Галланд Р., Соболева О. Что происходит в рассказе «Бобок»? / пер. с англ. Е. Погорелой // Вопросы литературы. - 2012. - № 4. - С. 293-312.

Мочульский К. В. Достоевский. Жизнь и творчество. - Париж : YMCA-Press, 1947 .

Неретина С. С. Слово и текст в средневековой культуре. История : миф, время, загадка. - М. : Гнозис, 1993.

Пушкин А. С. Собрание сочинений. В 10 т. Т. 9. Письма, $1815^{-18} 3^{0} /$ под ред. Д. Д. Благого, С. М. Бонди. - М. : Художественная литература, 1962.

Рубцов A. B. Политический нарциссизм в России : триумф пустоты / Forbes. 2016. - URL: http://www . forbes.ru/mneniya/vertikal/330685-politicheskii-na rtsissizm-v-rossii-triumf-pustoty (дата обр. 30 мая 2021).

Тоичкина A. В. Образ ада в «Записках из Мертвого дома». К теме Достоевский и Данте // Достоевский и мировая культура : Альманах / под ред. Н.Т. Ашимбаевой, Б. Н. Тихомирова. - СПб. : Серебряный век, 2012. - С. 161-173.

Хайдеггер M. Основные проблемы феноменологии / пер. с нем. А. Г. Чернякова. - СПб. : Высшая религиозно-философская школа, 2001.

Хамитов М. Р. Разговоры в царстве мёртвых : «Бобок» Ф. М. Достоевского // Достоевский : материалы и исследования. - 2016. - Т. 21. - С. 29-43.

Oesterley H. Gesta Romanorum. - Berlin : Weidmann, 1872. 
Neretina, S. S. 2021. "'Bobok' kak zerkalo udivleniya ['Bobok' as a Mirror of Surprise]" [in Russian]. Filosofiya. Zhurnal Vysshey shkoly ekonomiki [Philosophy. Journal of the Higher School of Economics] 5 (4), 157-174.

\section{SvetLana Neretina}

Doctor of Letters in Philosophy, Professor, Chief Research Fellow

RAS InStitute OF Philosophy (Moscow, RusSiA); ORCiD: 0000-0002-2063-062X

\section{"BOBOK" AS A MirRor OF SURPRISE}

Submitted: June 12, 2021. Reviewed: Sept. 19, 2021. Accepted: Jan. 01, 2021.

Abstract: The article considers the phenomenon, on the one hand, of a mirror, in which any thing, subject, person, first of all, is fixed in a reflection that makes it possible to observe oneself for the sake of self- understanding, on the other hand, the boundaries, mainly the boundaries between life and death, which can be crossed for the same purpose with the help of certain mental and physiological processes that affect the psycho-emotional state (in this case, sleep). Both phenomena, which seem similar, are in fact different: in one case, the emphasis is placed on contemplation, in the other - on speculation and hearing, tuned to the voice of another world. It is not by chance that Dostoevsky chose the place of the event: the cemetery as the border between life and death and the cemetery monument as a symbol of memory, where the hero "thought accordingly". Since the hero of the story is in an inadequate state after the funeral, the theme of menippea, a seriously funny genre, appears as if by itself, especially since M. M. Bakhtin considered the story "Bobok" "one of the greatest menippe in world literature." The author of the article considers Bakhtin's approach to the story from the standpoint of menippea justified, because he defines this genre not from the point of view of the effect it produces on the reader, but from the standpoint of the philosophy of action, which Bakhtin considered to be the true definition of this genre. The author draws attention to the "logic of turning", or tropo-logic, on the basis of which the story is built with its oxymorons, comparisons, and irony. The story, according to the author, is characterized not by ambivalence, but by the convergence of beginnings and ends. The philosophical thought of one of the characters in the story correlates the thoughts of the living and the dead, i.e. those who are in different space-time realities, so that they seem to be embedded in each other. This similarity, which does not deprive the story of carnivalization, which always deals with duality, is internally focused on the idea of like-mindedness having one source, anticipating the question that has not yet been born about the way of modifying being in possibility into being in reality.

Keywords: Narcissism, Bobok, Menippea, Dialogue, Border, Life, Death, Sleep.

DOI: $10.17323 / 2587-8719-2021-4-157-174$.

\section{REFERENCES}

Akel'kina, Ye. A. 2012. "Dante i Dostoyevskiy (retseptsiya dantovskogo opyta organizatsii povestvovaniya v 'Bozhestvennoy komedii' pri sozdanii 'Zapisok iz Mertvogo doma') [Dante and Dostoevsky (Reception of Dante's Experience of Organizing the Narrative in the 'Divine Comedy' when Creating 'Notes from the Dead House')]" [in Russian]. Vestnik Omskogo universiteta [Bulletin of Omsk University], no. 2: 394-399.

Alekseyev, V. 2013. "Tleniye tela kak metafora grekha [The Corruption of the Body as a Metaphor of Sin]: rasskaz Dostoyevskogo 'Bobok' [Dostoevsky's story 'Bobok']" [in Rus- 
sian]. Russian Lutheran. Accessed May 30, 2021. http://www.russianlutheran.org/strann ik/death_dostoevskiy.html.

Bakhtin, M. M. 1986. "K filosofii postupka [To the Philosophy of Action]" [in Russian]. In Filosofiya i sotsiologiya nauki i tekhniki [Philosophy and Sociology of Science and Technology] : Yezhegodnik 1984-1985 [Yearbook 1984-1985], ed. by I. T Frolov, 80-16o. Moskva [Moscow]: Nauka.

2002. Problemy poetiki Dostoyevskogo [Problems of Dostoevsky's Poetics] [in Russian]. Moskva [Moscow] and Augsburg: Im Werden Verlag.

Bibikhin, V. V. 2001. Slovo i sobytiye [Word and Event] [in Russian]. Moskva [Moscow]: URSS.

Bibler, V. S. 1991. Mikhail Mikhaylovich Bakhtin, ili Poetika kul'tury [Mikhail Mikhailovich Bakhtin, or the Poetics of Culture] [in Russian]. Moskva [Moscow]: Progress, Gnozis.

Gasparov, M. L. 2004. "Istoriya literatury kak tvorchestvo i issledovaniye [The History of Literature as Creativity and Research]: sluchay Bakhtina [The Case of Bakhtin]" [in Russian]. Vestnik gumanitarnoy nauki [Bulletin of the Humanities] 78 (6): 8-10.

Heidegger, M. 2001. Osnovnyye problemy fenomenologii [Die Grundprobleme der Phänomenologie] [in Russian]. Trans. from the German by A. G. Chernyakov. Sankt-Peterburg [Saint Petersburg]: Vysshaya religiozno-filosofskaya shkola.

Jackson, R. L. 1998. Iskusstvo Dostoyevskogo. Bredy i noktyurny [The Art of Dostoevsky] [in Russian]. Trans. from the English by T. Buzina and Ye. Gulyayeva. Moskva [Moscow]: Radiks.

Kantor, V. K. 2004. "Problema posmertnogo sushchestvovaniya (ot Platona do Dostoyevskogo). 'Bobok', rasskaz Dostoyevskogo [The Problem of Posthumous Existence (from Plato to Dostoevsky). 'Bobok', a story by Dostoevsky]" [in Russian]. Germanoslavica. Zeitschrift für germane-slavische Studien. Literatur und Wissen [Germanoslavica. Zeitschrift für germane-slavische Studien. Literatur und Wissen], no. 29: 63-76.

Khamitov, M. R. 2016. "Razgovory v tsarstve mërtvykh [Conversations in the Realm of the Dead]: 'Bobok' F. M. Dostoyevskogo ['Bobok' by F. M. Dostoevsky]" [in Russian]. Dostoyevskiy [Dostoevsky]: materialy i issledovaniya [Materials and Research] 21:29-43.

Latour, B. 2014. Peresborka sotsial'nogo [Reassembling the Social]: vvedeniye $v$ aktorno-setevuyu teoriyu [an Introduction to Actor-Network-Theory] [in Russian]. Trans. from the English by I. Polonskaya. Moskva [Moscow]: Izd. dom Vysshey shkoly ekonomiki.

Milner-Gulland, R., and O. Soboleva. 2012. "Chto proiskhodit v rasskaze 'Bobok' ? ['Excellent material, I see']" [in Russian], trans. from the English by Ye. Pogorelaya. Voprosy literatury [Questions of Literature], no. 4: 293-312.

Mochul'skiy, K. V. 1947. Dostoyevskiy. Zhizn' i tvorchestvo [Dostoevsky. Life and Work] [in Russian]. Parizh: YMCA-Press.

Neretina, C. C. 1993. Slovo i tekst v srednevekovoy kul'ture. Istoriya [Word and Text in Medieval Culture. History]: mif, vremya, zagadka [Myth, Time, Enigme] [in Russian]. Moskva [Moscow]: Gnozis.

Oesterley, H. 1872. Gesta Romanorum [in German]. Berlin: Weidmann.

Pushkin, A. S. 1962. Pis'ma, 1815-1830 [Letters, 1815-1830] [in Russian]. Vol. 9 of Sobraniye sochineniy [Sollected Works], ed. by D. D. Blagoy and S. M. Bondi. 10 vols. Moskva [Moscow]: Khudozhestvennaya literatura.

Rubtsov, A. V. 2016. "Politicheskiy nartsissizm v Rossii [Political Narcissism in Russia]: triumf pustoty [The Triumph of Emptiness]" [in Russian]. Forbes. Accessed May 30, 2021. http:// www.forbes.ru/mneniya/vertikal/330685-politicheskii-nartsissizm-v-rossii-triumf-pust oty. 
Toichkina, A. V. 2012. "Obraz ada v 'Zapiskakh iz Mertvogo doma'. K teme Dostoyevskiy i Dante [The Image of Hell in 'Notes from the Dead House'. To the Topic Dostoevsky and Dante]" [in Russian]. In Dostoyevskiy i mirovaya kul'tura [Dostoevsky and World Culture] : Al'manakh [Almanac], ed. by N. T. Ashimbayeva and B. N. Tikhomirov, 161-173. Sankt-Peterburg [Saint Petersburg]: Serebryanyy vek.

Voloshinov, V. N. [Bakhtin, M. M.] 1993. Marksizm i filosofiya yazyka [Marxism and the Philosophy of Language]: osnovnyye problemy semiologicheskogo metoda v nauke o yazyke [The Main Problems of the Semiological Method in the Science of Language] [in Russian]. Moskva [Moscow]: Labirint.

Yevlampiyev, I. I. 2012. Filosofiya cheloveka v tvorchestve F. Dostoyevskogo (ot rannikh proizvedeniy $k$ "Brat'yam Karamazovym") [The Philosophy of Man in the Work of F. Dostoevsky (From the Early Works to the "Brothers Karamazov")] [in Russian]. Moskva [Moscow]: RKhGA. 